\title{
Oxovanadium(IV)-sulfite compounds: Synthesis and structural and physical studies*
}

\author{
George I. Chilas ${ }^{1}$, Haralampos N. Miras ${ }^{1}$, Manolis J. Manos ${ }^{1}$, \\ J. Derek Woollins ${ }^{2}$, Alexandra M. Z. Slawin ${ }^{2}$, Marios Stylianou ${ }^{3}$, \\ Anastasios D. Keramidas ${ }^{3}$, and Themistoklis A. Kabanos ${ }^{1, \ddagger}$ \\ ${ }^{1}$ Department of Chemistry, Section of Inorganic and Analytical Chemistry, \\ University of loannina, 45110 loannina, Greece; ${ }^{2}$ Department of Chemistry, \\ University of St. Andrews, UK; ${ }^{3}$ University of Cyprus, 1678 Nicosia, Cyprus
}

\begin{abstract}
Reaction of $\mathrm{V}^{\mathrm{IV}} \mathrm{OCl}_{2}$ in strongly acidic aqueous solution with either $\left(\mathrm{NH}_{4}\right)_{2} \mathrm{SO}_{3}$ or $\mathrm{Na}_{2} \mathrm{SO}_{3}$ and $\mathrm{Bu}_{4} \mathrm{NBr}$ at $\sim 70{ }^{\circ} \mathrm{C}$ in the $\mathrm{pH}$ range 2.5-4.5 gives the clusters $\left(\mathrm{NH}_{4}\right)_{2}\left\{\left[\mathrm{~V}_{4}^{\mathrm{IV}}\left(\mu_{4}-\mathrm{O}\right)_{2}\left(\mu_{3}-\mathrm{OH}\right)_{2}\right]\left(\mathrm{V}^{\mathrm{IV}} \mathrm{O}\right)_{2}\left(\mu_{3}-\mathrm{SO}_{3}\right)_{4} \mathrm{O}_{4}\left(\mathrm{H}_{2} \mathrm{O}\right)_{2}\right\}$ and $\left(n-\mathrm{Bu}_{4} \mathrm{~N}\right)_{2}\left\{\left[\mathrm{~V}_{4}{ }^{\mathrm{IV}}\left(\mu_{4^{-}}\right.\right.\right.$ $\left.\left.\mathrm{O})_{2}\left(\mu_{3}-\mathrm{OH}\right)_{2}\right]\left(\mathrm{V}^{\mathrm{IV}} \mathrm{O}\right)_{2}\left(\mu_{3}-\mathrm{SO}_{3}\right)_{4} \mathrm{O}_{4}\left(\mathrm{H}_{2} \mathrm{O}\right)_{2}\right\}$, respectively. Reaction of $\mathrm{NH}_{4} \mathrm{~V}^{\mathrm{V}} \mathrm{O}_{3}$ with $\left(\mathrm{NH}_{4}\right)_{2} \mathrm{SO}_{3}$ resulted in the isolation of the first compound. When the latter reaction is carried out in the presence of $\mathrm{MgO}$, compound $\left(\mathrm{NH}_{4}\right)\left[\mathrm{V}^{\mathrm{IV}} \mathrm{O}\left(\mathrm{SO}_{3}\right)_{1.5} \mathrm{H}_{2} \mathrm{O}\right]_{\infty} \cdot 2.5 \mathrm{H}_{2} \mathrm{O}$ was isolated instead. Compound $\left(n-\mathrm{Bu}_{4} \mathrm{~N}\right)_{2}\left\{\left[\mathrm{~V}_{4} \mathrm{IV}\left(\mu_{4}-\mathrm{O}\right)_{2}\left(\mu_{3}-\mathrm{OH}\right)_{2}\right]\left(\mathrm{V}^{\mathrm{IV}} \mathrm{O}\right)_{2}\left(\mu_{3}-\mathrm{SO}_{3}\right)_{4} \mathrm{O}_{4}\left(\mathrm{H}_{2} \mathrm{O}\right)_{2}\right\}$ and $\left(\mathrm{NH}_{4}\right)\left[\mathrm{V}^{\mathrm{IV}} \mathrm{O}\left(\mathrm{SO}_{3}\right)_{1.5} \mathrm{H}_{2} \mathrm{O}\right]_{\infty} \cdot 2.5 \mathrm{H}_{2} \mathrm{O}$ were characterized by $\mathrm{X}$-ray structure analysis. The crystal structure of species $\left(n-\mathrm{Bu}_{4} \mathrm{~N}\right)_{2}\left\{\left[\mathrm{~V}_{4}{ }^{\mathrm{IV}}\left(\mu_{4}-\mathrm{O}\right)_{2}\left(\mu_{3}-\mathrm{OH}\right)_{2}\right]\left(\mathrm{V}^{\mathrm{IV}} \mathrm{O}\right)_{2}\left(\mu_{3}-\mathrm{SO}_{3}\right)_{4} \mathrm{O}_{4}\left(\mathrm{H}_{2} \mathrm{O}\right)_{2}\right\}$ revealed a unprecedented hexanuclear cluster consisting of a cubane core $\left[\mathrm{M}_{4}\left(\mu_{4}-\mathrm{O}\right)_{2}\left(\mu_{3^{-}}\right.\right.$ $\mathrm{OH})_{2}$ ] connected to two other metal atoms through the core oxo-groups and four $\mu_{3}-\mathrm{SO}_{3}$ bridges. Compound $\left(\mathrm{NH}_{4}\right)\left[\mathrm{V}^{\mathrm{IV}} \mathrm{O}\left(\mathrm{SO}_{3}\right)_{1.5} \mathrm{H}_{2} \mathrm{O}\right]_{\infty} \cdot 2.5 \mathrm{H}_{2} \mathrm{O}$ represents a rare example of an open-framework species prepared under mild conditions. Cyclic voltammetric examination of compound $\left(n-\mathrm{Bu}_{4} \mathrm{~N}\right)_{2}\left\{\left[\mathrm{~V}_{4}{ }^{\mathrm{IV}}\left(\mu_{4}-\mathrm{O}\right)_{2}\left(\mu_{3}-\mathrm{OH}\right)_{2}\right]\left(\mathrm{V}^{\mathrm{IV}} \mathrm{O}\right)_{2}\left(\mu_{3}-\mathrm{SO}_{3}\right)_{4} \mathrm{O}_{4}\left(\mathrm{H}_{2} \mathrm{O}\right)_{2}\right\}$ revealed a redox process which was assigned to the oxidation of one core of vanadium(IV) to vana$\operatorname{dium}(\mathrm{V})$.
\end{abstract}

Keywords: Oxovanadium; sulfite; vanadium clusters; vanadium(IV); electrochemistry.

\section{INTRODUCTION}

In the last two decades, polyoxometalate derivatives incorporating inorganic ligands [1] and, in particular, the tetrahedral phosphate [2] ion have been intensively investigated because this family of inorganic clusters has a wide variety of compositions and considerable structural versatility [3]. Also, inorganic clusters of this kind display important magnetic [4], optical [3], and catalytic properties [3]. In marked contrast, heteropolyanions containing the pyramidal sulfite anion as ligand are very limited [5]. The sulfite anion has $C_{3 \mathrm{v}}$ symmetry and contains a nonbonding, but stereochemically active pair of electrons, and its metal-compounds may potentially display nonlinear optical (NLO) properties [6], which are observed in the metal-selenites [7] and metal-iodates [8]. Metal-sulfite chemistry is very

\footnotetext{
*Paper based on a presentation at the $4^{\text {th }}$ International Symposium on Chemistry and Biological Chemistry of Vanadium, Szeged, Hungary, 3-5 September 2004. Other presentations are published in this issue, pp. 1497-1640.

¥Corresponding author: E-mail: tkampano@cc.uoi.gr
} 
attractive in view of its potential for restricting the serious environmental problem of acid rain [9]. $\mathrm{V}_{2} \mathrm{O}_{5}$ is used as an industrial catalyst for the production of sulfuric acid, through oxidation of $\mathrm{SO}_{2}$ to $\mathrm{SO}_{3}$ at $400-600{ }^{\circ} \mathrm{C}$. Crude oil may contain up to $4 \%$ vanadium mainly in the form of $\mathrm{V}^{\mathrm{IV}} \mathrm{O}^{2+}$-porphyrines [10], which are transformed to $\mathrm{V}_{2} \mathrm{O}_{5}$ on burning. The existence of $\mathrm{V}_{2} \mathrm{O}_{5}$ in the atmosphere may cause health hazards and the oxidation of $\mathrm{SO}_{2}$ to $\mathrm{SO}_{3}$ (acid rain). Thus, it is of vital importance to study the interaction of vanadium with the sulfite anion. Herein, we report the synthesis and structural and physicochemical characterization of the oxovanadium(IV)-sulfite clusters $\left(\mathrm{NH}_{4}\right)_{2}\left\{\left[\mathrm{~V}_{4}{ }^{\mathrm{IV}}\left(\mu_{4^{-}}\right.\right.\right.$ $\left.\left.\mathrm{O})_{2}\left(\mu_{3}-\mathrm{OH}\right)_{2}\right]\left(\mathrm{V}^{\mathrm{IV}} \mathrm{O}\right)_{2}\left(\mu_{3}-\mathrm{SO}_{3}\right)_{4} \mathrm{O}_{4}\left(\mathrm{H}_{2} \mathrm{O}\right)_{2}\right\} \quad \mathbf{1}, \quad\left(n-\mathrm{Bu}_{4} \mathrm{~N}\right)_{2}\left\{\left[\mathrm{~V}_{4}{ }^{\mathrm{IV}}\left(\mu_{4}-\mathrm{O}\right)_{2}\left(\mu_{3}-\mathrm{OH}\right)_{2}\right]\left(\mathrm{V}^{\mathrm{IV}}\right)_{2}\left(\mu_{3^{-}}\right.\right.$ $\left.\left.\mathrm{SO}_{3}\right)_{4} \mathrm{O}_{4}\left(\mathrm{H}_{2} \mathrm{O}\right)_{2}\right\} 2$, and $\left(\mathrm{NH}_{4}\right)\left[\mathrm{V}^{\mathrm{IV}} \mathrm{O}\left(\mathrm{SO}_{3}\right)_{1.5} \mathrm{H}_{2} \mathrm{O}\right]_{\infty} \cdot 2.5 \mathrm{H}_{2} \mathrm{O} 3$.

\section{RESULTS AND DISCUSSION}

\section{Synthesis of compounds 1-3}

The synthesis of the oxovanadium(IV)-sulfite compounds is summarized in Scheme 1. It is obvious from Scheme 1 that irrespective of the conditions used in the interaction of vanadium- $\mathrm{SO}_{3}{ }^{2-}$ system, more specifically: (i) source of vanadium $\left(\mathrm{V}^{\mathrm{IV}} \mathrm{OCl}_{2}\right.$ or $\mathrm{NH}_{4} \mathrm{~V}^{\mathrm{V}} \mathrm{O}_{3}$ ); (ii) temperature (room temperature or 70-80 ${ }^{\circ} \mathrm{C}$ ); (iii) counterion $\left(\mathrm{Na}^{+}, \mathrm{NH}_{4}{ }^{+}\right.$, or $n-\mathrm{Bu}_{4} \mathrm{~N}^{+}$); and (iv) $\mathrm{pH}$ ( $\mathrm{pH}$ range $2.5-4.5$ ) the same $\mathrm{V}^{\mathrm{IV}} / \mathrm{SO}_{3}{ }^{2-}$ cluster, $\left\{\left[\mathrm{VV}_{4}{ }^{\mathrm{IV}}\left(\mu_{4}-\mathrm{O}\right)_{2}\left(\mu_{3}-\mathrm{OH}\right)_{2}\right]\left(\mathrm{V}^{\mathrm{IV}} \mathrm{O}\right)_{2}\left(\mu_{3}-\mathrm{SO}_{3}\right)_{4} \mathrm{O}_{4}\left(\mathrm{H}_{2} \mathrm{O}\right)_{2}\right\}^{2-}$, was isolated. When $\mathrm{NH}_{4} \mathrm{~V}^{\mathrm{V}} \mathrm{O}_{3}$ was used as a vanadium source in the presence of $\mathrm{Mg}^{2+}$ as a counterion and $\left(\mathrm{NH}_{4}\right)_{2} \mathrm{SO}_{3}$ as a source of the sulfite anion a new oxovanadium(IV)-sulfite species, $\left(\mathrm{NH}_{4}\right)\left[\mathrm{V}^{\mathrm{IV}} \mathrm{O}\left(\mathrm{SO}_{3}\right)_{1.5} \mathrm{H}_{2} \mathrm{O}\right]_{\infty} \cdot 2.5 \mathrm{H}_{2} \mathrm{O} 3$, was isolated. The role of $\mathrm{Mg}^{2+}$ in the isolation of compound 3 is as yet unknown. Compounds $\mathbf{1}$ and $\mathbf{2}$ were prepared in a different way from that reported in the literature [5c], and the yield of compound $\mathbf{2}$ was almost quantitative ( $90 \%)$. When compounds $\mathbf{1}$ and $\mathbf{2}$ were prepared using a $\mathrm{V}^{\mathrm{IV}}$ compound as a vanadium source, the $\mathrm{SO}_{3}{ }^{2-}$ plays a dual role as ligand and in raising the $\mathrm{pH}$ value of the solution, whereas the use of a $\mathrm{V}^{\mathrm{V}}$ compound as the vanadium source introduces an additional role for the sulfite anion, as a reducing agent. 


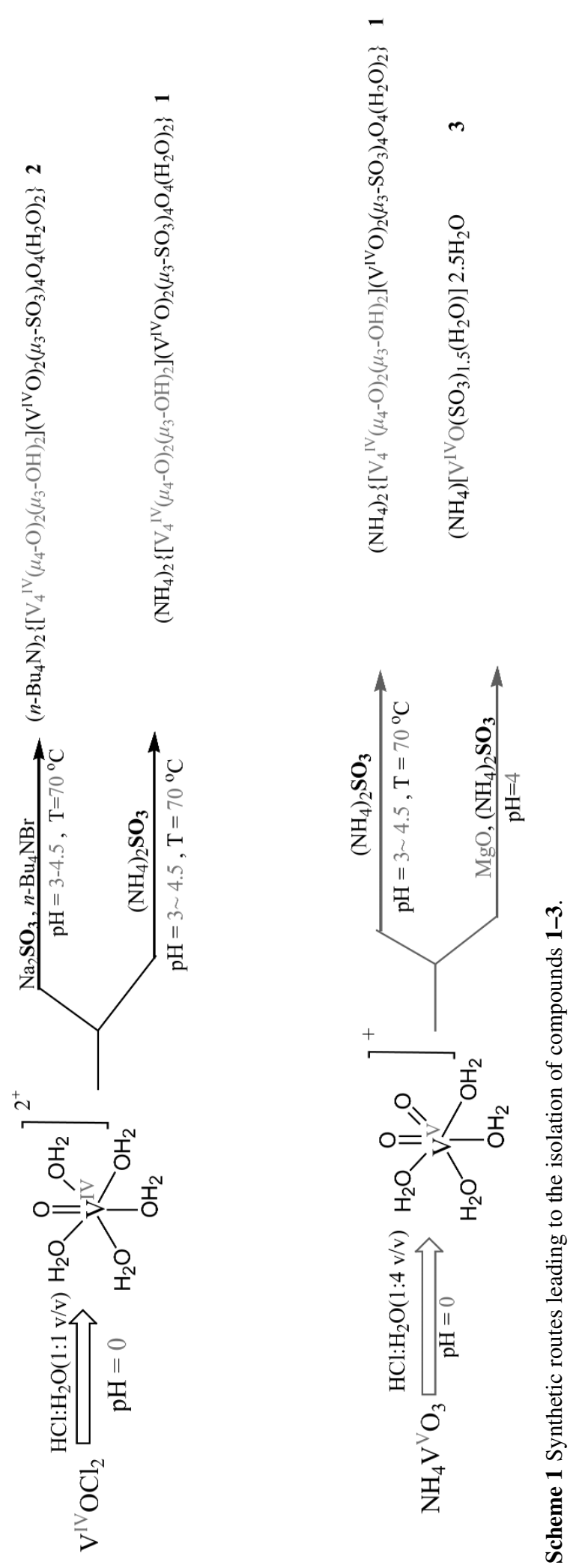

(C) 2005 IUPAC, Pure and Applied Chemistry 77, 1529-1538 


\section{X-ray crystallography}

Crystal data and details of data collection for compounds $\mathbf{2}$ and $\mathbf{3}$ are listed in Table 1 . The core of the hexanuclear anion of $\mathbf{2},\left\{\left[\mathrm{V}_{4}{ }^{\mathrm{IV}}\left(\mu_{4}-\mathrm{O}\right)_{2}\left(\mu_{3}-\mathrm{OH}\right)_{2}\right]\left(\mathrm{V}^{\mathrm{IV}} \mathrm{O}\right)_{2}\left(\mu_{3}-\mathrm{SO}_{3}\right)_{4} \mathrm{O}_{4}\left(\mathrm{H}_{2} \mathrm{O}\right)_{2}\right\}^{2-}$ (Fig. 1), consists of a distorted cubane unit, $\left[\mathbf{V}_{4}{ }_{4} \mathbf{I V}_{\mathbf{2}}(\mathbf{O H})_{2}\right]$, which is comprised of four, triply edge-sharing $\mathrm{V}^{\mathrm{IV}} \mathrm{O}_{6}$ octahedra, each having an oxo group $(\mathrm{V}=\mathrm{O} 1.58 \AA$ ) in a position trans to a long $\mathrm{V}-\mathrm{O}$ bond $(2.36 \AA)$. The four equatorial V-O bonds are similar in length, at approximately $2.2 \AA$. The two square-pyramidal $\mathrm{O}_{5} \mathrm{~V}^{\mathrm{IV}}$ units are coordinated to the vanadium ions of the $\left[\mathrm{V}_{4}{ }^{\mathrm{IV}} \mathrm{O}_{2}(\mathrm{OH})_{2}\right]$ fragment through one $\mu_{4}-\mathrm{O}^{2-}$ and two $\mu_{3}-\mathrm{SO}_{3}{ }^{2-}$ bridges. The two $\mu_{4}$-oxygen atoms $\mathrm{O}(4)$ and $\mathrm{O}(4 \mathrm{~A})$ connect the network of six vanadium(IV) ions and possess almost a trigonal pyramidal geometry. The hexanuclear $\mathrm{V}^{\mathrm{IV}} \leftarrow\left[\mathrm{V}_{4}{ }^{\mathrm{IV}}\left(\mu_{4}-\mathrm{O}\right)_{2}\left(\mu_{3^{-}}\right.\right.$ $\left.\mathrm{OH})_{2}\right] \rightarrow \mathrm{V}^{\mathrm{IV}}$ cluster represents a novel structural motif [11]. The temperature dependence of the susceptibility data for compound $\mathbf{2}$ revealed an overall ferromagnetic behavior [5b].

Table 1 Summary of crystallographic data for compounds 2 and 3 .

\begin{tabular}{lcc}
\hline Compound & $\mathbf{2}$ & $\mathbf{3}$ \\
\hline Formula & $\mathrm{C}_{32} \mathrm{H}_{78} \mathrm{~N}_{2} \mathrm{O}_{24} \mathrm{~S}_{4} \mathrm{~V}_{6}$ & $\mathrm{H}_{11} \mathrm{NO}_{9} \mathrm{~S}_{1.5} \mathrm{~V}$ \\
$\mathrm{M}_{\mathrm{r}}$ & 1308.83 & 268.13 \\
$\alpha[\AA]$ & $20.48910(10)$ & $7.0680(17)$ \\
$\mathrm{b}[\AA]$ & $16.6679(4)$ & $12.536(3)$ \\
$\mathrm{c}[\AA]$ & $18.0218(3)$ & $8(5)$ \\
$\alpha\left[^{\circ}\right]$ & 90 & 90 \\
$\beta\left[{ }^{\circ}\right]$ & $111.3460(10)$ & 90 \\
$\gamma\left[{ }^{\circ}\right]$ & 90 & 90 \\
$\mathrm{~V}\left[\AA^{3}\right]$ & $5732.42(17)$ & $1769.2(7)$ \\
$\mathrm{Z}$ & 4 & 8 \\
$\rho_{\text {calc' }}\left[\mathrm{Mgm}^{-3}\right]$ & 1.517 & 2.013 \\
Space group & $I 2 / \alpha$ & $P b c m$ \\
$\mathrm{~T}[\mathrm{~K}]$ & $293(2)$ & $293(2)$ \\
$\mu\left[\mathrm{mm}{ }^{-1}\right]$ & 1.156 & 1.500 \\
$\mathrm{R} 1($ final & 0.0274 & 0.0586 \\
WR2 & 0.0693 & 0.1140 \\
\hline
\end{tabular}

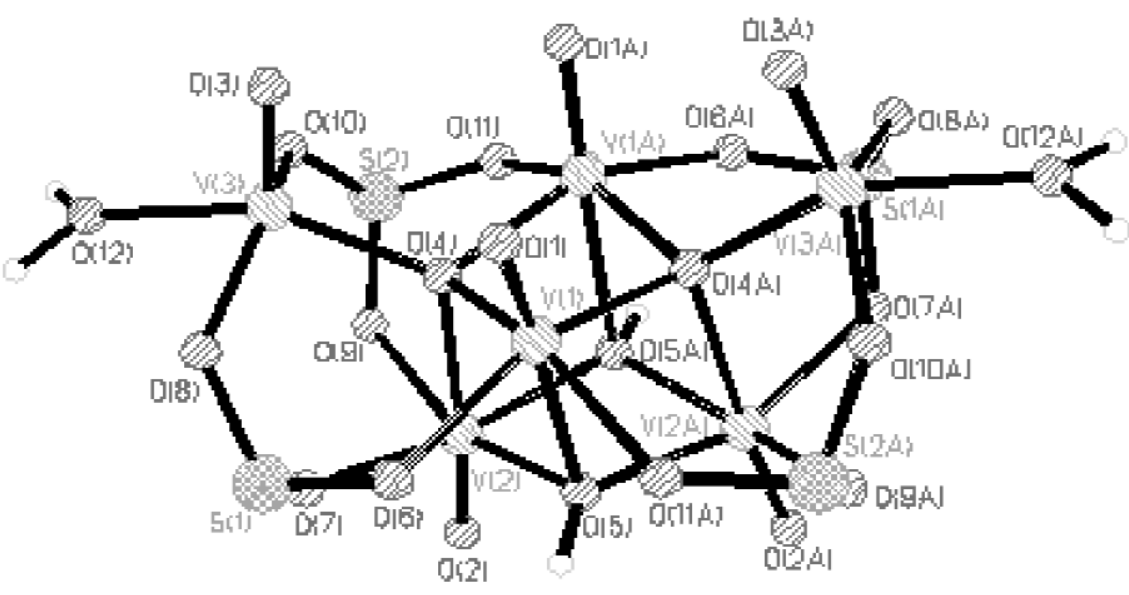

Fig. 1 Ball-and-stick representation of compound 2. 
Compound 3 crystallizes in the orthorhombic space group Pbcm and exhibits a 2D open-framework structure. The crystallographically unique vanadium ion of $\mathbf{3}$ resides in a distorted octahedron comprised of four equatorial sulfite oxygen atoms, as well as an oxygen atom from a water molecule and an oxo group, which occupy the axial positions (Fig. 2). The 2D structure of compound 3 (Fig. 3) is a layered net of $\mathrm{VO}_{6}$ octahedra, each sharing four corners with four adjacent sulfite trigonal pyramids. The connectivity between the $\mathrm{VO}_{6}$ octahedra and the sulfite trigonal pyramids creates an openframework compound with eight- and four-ring windows.

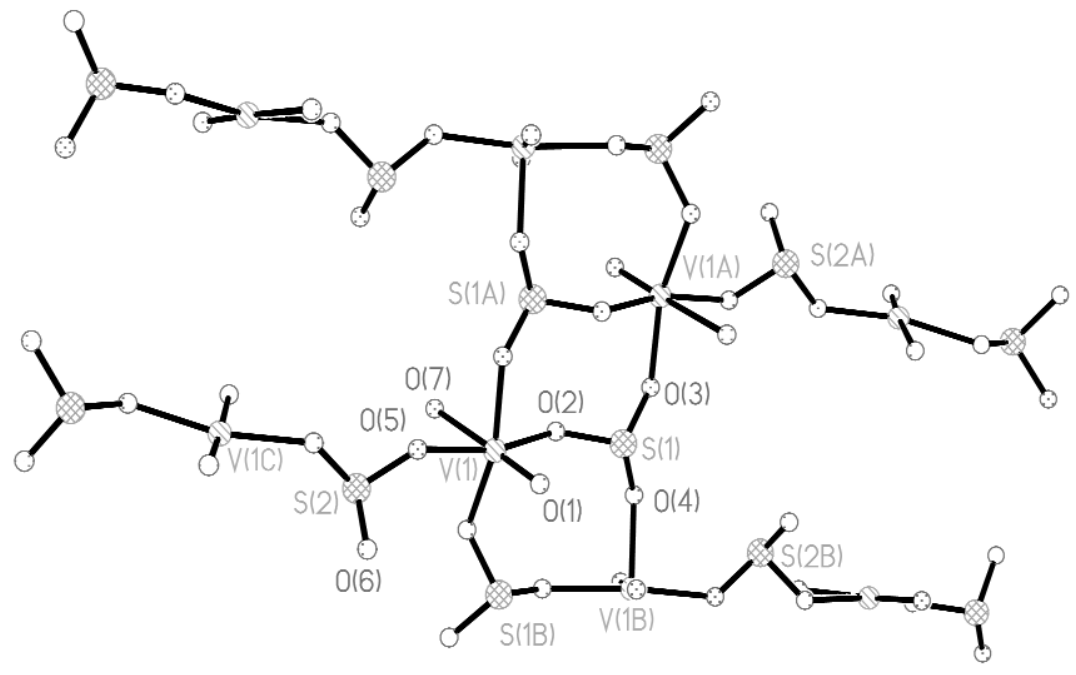

Fig. 2 Ball-and-stick representation of compound $\mathbf{3}$.

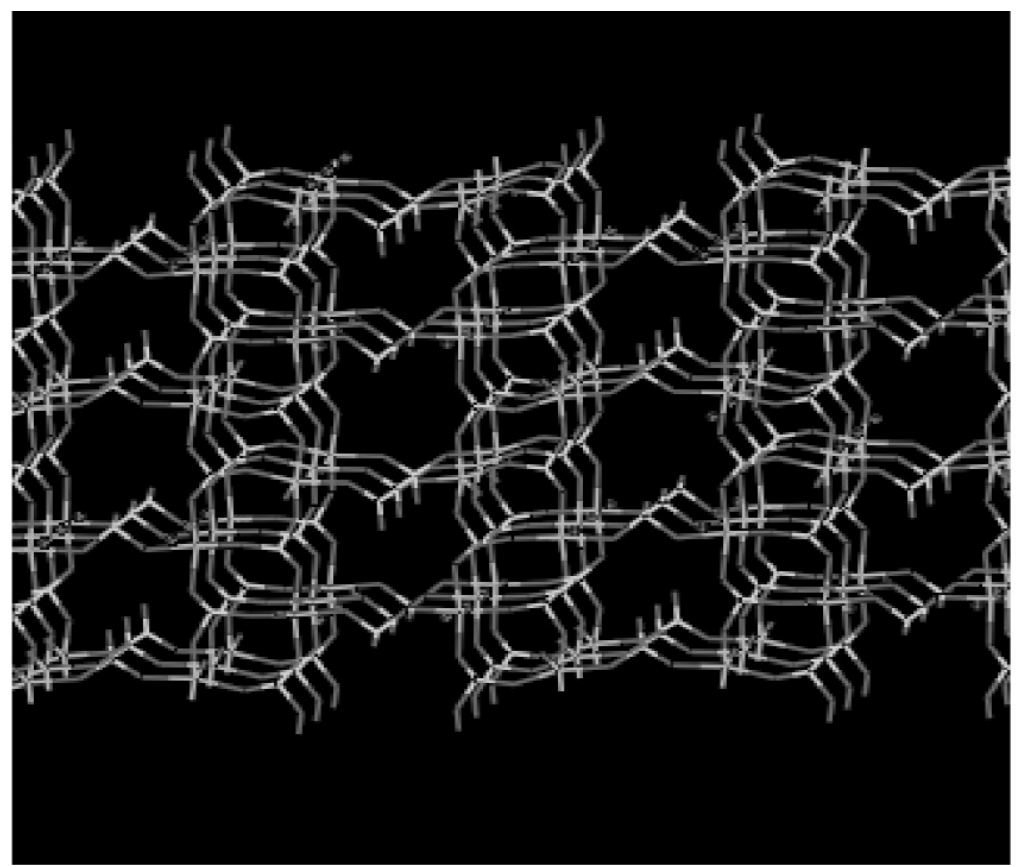

Fig. 3 2D structure of compound 3. 
In marked contrast to polyoxometalates (POMs) containing the tetrahedral phosphate group, the $\mathrm{POM}-\mathrm{SO}_{3}{ }^{2-}$ chemistry is rather limited. More specifically, except of the POM-sulfite compounds reported in this paper the following molybdenum-sulfite species have been reported: $\left[\mathrm{Mo}_{18} \mathrm{O}_{54}\left(\mu_{9^{-}}\right.\right.$ $\left.\left.\mathrm{SO}_{3}\right)_{2}\right]^{4-16-} 4$ [5d], which is a $\mathrm{M}_{18}$ Dawson structural-type species, $\left[\mathrm{Mo}_{5} \mathrm{O}_{15}\left(\mu_{5}-\mathrm{SO}_{3}\right)_{2}\right]^{4-} \mathbf{5}$ [5a], $\left[\left(\mathrm{Mo}_{2} \mathrm{O}_{4}\right)_{6}\left(\mu_{2}-\mathrm{SO}_{3}\right)_{12}\left(\mu_{3}-\mathrm{SO}_{3}\right)_{4}\right]^{20-} \mathbf{6}[5 \mathrm{~b}],\left\{\mathrm{Na}\left[\left(\mathrm{Mo}_{2} \mathrm{O}_{4}\right)_{3}\left(\mu_{2}-\mathrm{SO}_{3}\right)_{3}\left(\mu_{6}-\mathrm{SO}_{3}\right)\right]_{2}\right\}^{15-} \mathbf{7}^{[5 \mathrm{~b}] \text {, and }}$ $\left[\left(\mathrm{Mo}_{2} \mathrm{O}_{4}\right)\left(\mathrm{SO}_{3}\right)_{4}\left(\mu_{2}-\mathrm{SO}_{3}\right)\right]^{8-} \mathbf{8}[5 \mathrm{~b}]$. For compounds 4, 5, and 7, their molybdenum-phosphate analogs have been reported in the literature [14]. Compound $\mathbf{6}$ is completely different from the $\mathrm{Mo}_{12}-\mathrm{PO}_{4}{ }^{3-}$ Keggin analog [3a,14e]. The structural features of the vanadium- $\mathrm{SO}_{3}{ }^{2-}$ compounds $\mathbf{2}$ and $\mathbf{3}$ have no vanadium- $\mathrm{PO}_{4}{ }^{3-}$ precedents. No tungsten- $\mathrm{SO}_{3}{ }^{2-}$ or mixed-metal (V/Mo) $-\mathrm{SO}_{3}{ }^{2-}$ species have been reported thus far. From all these data, it is crystal clear that $\mathrm{SO}_{3}{ }^{2-}$ gives a very rich chemistry with unprecedented structural motifs, new sulfite bonding modes $\left(\mu_{9}, \mu_{6}, \mu_{3}\right)$, and novel physical properties.

\section{Electrochemistry}

A cyclic voltammetric examination of compound 2 in acetonitrile at $\sim 0{ }^{\circ} \mathrm{C}$ revealed an one electron quasi-reversible redox process at $0.67 \mathrm{~V}$ vs. NHE (Fig. 4) and two irreversible redox processes at 1.25 and $1.42 \mathrm{~V}$ vs. NHE the quasi-reversible redox process at $0.67 \mathrm{~V}$ was assigned to the oxidation of the $\mathrm{V}^{\mathrm{IV}}$ atom to $\mathrm{V}^{\mathrm{V}}$ and is summarized in Scheme 2. The irreversible redox processes are assigned to the oxidation of the sulfite groups, and this assignment is based on the fact that $\mathrm{Na}_{2} \mathrm{SO}_{3}$ gives two irreversible peaks at $\boldsymbol{E}$ /values very close to those observed for $\mathbf{2}$ (Table 2). When the switching potential is in the range, $0.3-1.4 \mathrm{~V}$, the metal-based redox process is not influenced by the first oxidation of the sulfite groups as shown in Fig. 4b, and this of course means that the hexanuclear species retains its integrity in solution. In marked contrast, when the switching potential is in the range, $0.3-1.6 \mathrm{~V}$, then the second oxidation of the sulfites results in the disappearance of $\mathrm{V}^{\mathrm{IV}} / \mathrm{V}^{\mathrm{V}}$ redox couple (Fig. 4c), presumably because of the decomposition of compound 2 .

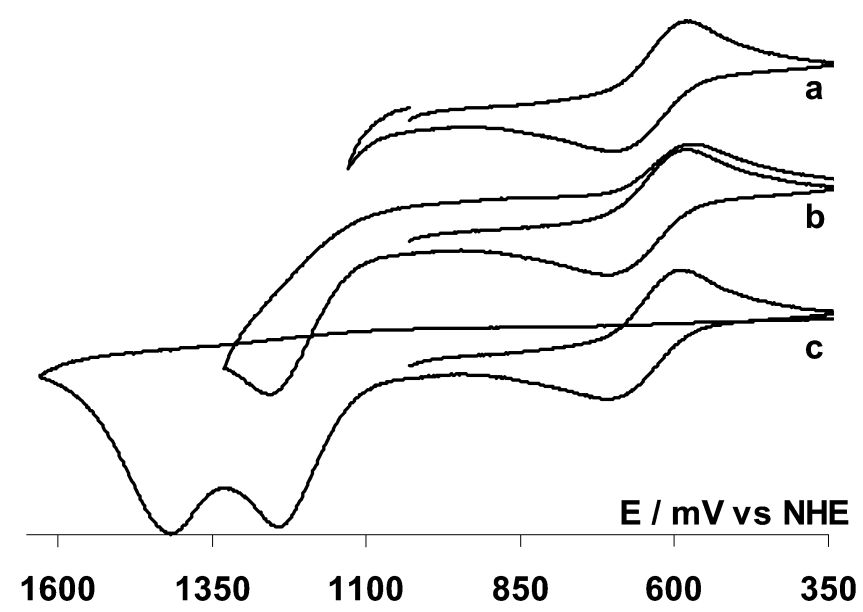

Fig. 4 Cyclic voltammograms of 2 in $\mathrm{CH}_{3} \mathrm{CN}$ at various switching potentials. 


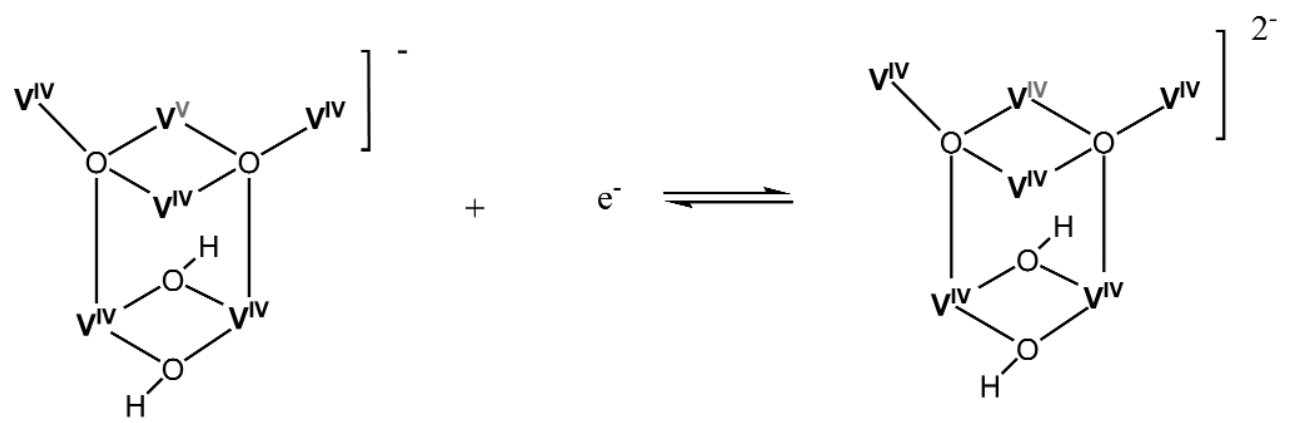

Scheme 2 Oxidation of the $\mathrm{V}^{\mathrm{IV}}$ atom to $\mathrm{V}^{\mathrm{V}}$.

Table 2 Redox potentials (vs. NHE) of compound 2 and $\mathrm{Na}_{2} \mathrm{SO}_{3}$ in $\mathrm{CH}_{3} \mathrm{CN}$ $\left(0{ }^{\circ} \mathrm{C}\right)$ measured from cyclic voltammograms (scan rate $100 \mathrm{mV} / \mathrm{s}$ ).

\begin{tabular}{lccccc}
\hline Compound & $E_{\mathrm{p}, \mathrm{c}}(\mathrm{V})$ & $E_{\mathrm{p}, \mathrm{a}}(\mathrm{V})$ & $\Delta E(\mathrm{mV})$ & $E_{1 / 2}$ & $\begin{array}{c}\text { Number of } \\
\text { electrons }\end{array}$ \\
\hline $\mathbf{2}$ & +0.62 & +0.72 & 100 & +0.67 & 1.0 \\
& & +1.25 & & & 2.0 \\
& & +1.42 & & & \\
$\mathbf{N a}_{\mathbf{2}} \mathbf{S O}_{3}$ & & +1.21 & & & \\
& & +1.39 & & & \\
\hline
\end{tabular}

\section{CONCLUSION}

In conclusion, we have prepared a series of oxovanadium(IV)-sulfite compounds by simply reacting $\mathrm{V}^{\mathrm{IV}} \mathrm{OCl}_{2}$ or $\mathrm{NH}_{4} \mathrm{~V}^{\mathrm{V}} \mathrm{O}_{3}$ with either $\left(\mathrm{NH}_{4}\right)_{2} \mathrm{SO}_{3}$ or $\mathrm{Na}_{2} \mathrm{SO}_{3}$. These $\mathrm{V}^{\mathrm{IV}} \mathrm{O}^{2+}-\mathrm{SO}_{3}{ }^{2-}$ species represent the first examples of vanadium-sulfite compounds. The hexanuclear oxovanadium(IV)-sulfite cluster, $\left(n-\mathrm{Bu}_{4} \mathrm{~N}\right)_{2}\left\{\left[\mathrm{~V}_{4}{ }^{\mathrm{IV}}\left(\mu_{4}-\mathrm{O}\right)_{2}\left(\mu_{3}-\mathrm{OH}\right)_{2}\right]\left(\mathrm{V}^{\mathrm{IV}} \mathrm{O}\right)_{2}\left(\mu_{3}-\mathrm{SO}_{3}\right)_{4} \mathrm{O}_{4}\left(\mathrm{H}_{2} \mathrm{O}\right)_{2}\right\} 2$, exhibits a unique structural motif, not only for vanadium but for any metal atom. The $2 \mathrm{D}$ structure of compound $\mathbf{3}$ represents a rare example of an open-framework compound isolated under mild conditions $\left(\sim 20^{\circ} \mathrm{C}\right)$. The vanadium-sulfite chemistry is completely different from the vanadium-phosphate chemistry from the structural point of view. The temperature dependence of the magnetic susceptibility data for compound 2 revealed an overall ferromagnetic behavior, which is unexpected for $\mathrm{V}^{\mathrm{IV}}$ clusters. The preparation of 1-3 and of the molybdenum(V/VI)- $\mathrm{SO}_{3}{ }^{2-}$ compounds further emphasizes the great ability of the seemingly pedestrian sulfite anion to act as a ligand in polyoxometalates. Taking into account the findings from the vanadium- $\mathrm{SO}_{3}{ }^{2-}$ and molybdenum- $\mathrm{SO}_{3}{ }^{2-}$ chemistry, it is certain that new metal- $\mathrm{SO}_{3}{ }^{2-}$ compounds would appear in the near future with novel structural features, new modes of coordination for the $\mathrm{SO}_{3}{ }^{2-}$ group, and unique physical properties. The synthesis of new vanadium(IV)- $\mathrm{SO}_{3}{ }^{2-}$ and molybdenum(V/VI)- $\mathrm{SO}_{3}{ }^{2-}$ species by variation of temperature, pressure, counterions, and $\mathrm{pH}$ as well as of tungsten(VI)- $\mathrm{SO}_{3}{ }^{2-}$ and mixed-metal vanadium-molybdenum- $\mathrm{SO}_{3}{ }^{2-}$ compounds are future challenges. In addition, the NLO properties of the noncentrosymmetric metal-sulfite clusters should be studied.

\section{EXPERIMENTAL SECTION}

\section{Physical measurements}

IR spectra of the various compounds dispersed in $\mathrm{KBr}$ pellets were recorded on a Perkin-Elmer Spectrum GX FT-IR spectrometer, CV measurements were carried out using a PAR model 273A elec- 
trochemistry system. Platinum wire reference and auxiliary electrodes and a platinum disc working electrode were used in a three-electrode configuration. Ferrocene (0.665 V vs. NHE) [15] was used as internal reference. The supporting electrolyte was $n-\mathrm{Bu}_{4} \mathrm{NClO}_{4}(\sim 0.1 \mathrm{M})$, and the solute concentration was $\sim 10^{-3} \mathrm{M}$. The half-wave potential $E_{298}^{\circ}$ was set equal to $0.5\left(E_{\mathrm{pa}}+E_{\mathrm{pc}}\right)$, where $E_{\mathrm{pa}}$ and $E_{\mathrm{pc}}$ are anodic and cathodic cyclic voltammetric peak potentials, respectively. The number of electrons for each wave was calculated from rotating disk voltammograms and by comparing the height of the peaks in the rotating disk voltammograms. All experiments were carried out under a dinitrogen atmosphere in dry $\mathrm{CH}_{3} \mathrm{CN}$; because compound 2 decomposes slowly in $\mathrm{CH}_{3} \mathrm{CN}$, the solutions were cooled at $0{ }^{\circ} \mathrm{C}$ in order to reduce the decomposition rate. The decomposition of the complex was monitored by $\mathrm{CV}$, and no decomposition was observed during the experiments, over a period of $30 \mathrm{~min}$.

\section{Synthesis of $\left(\mathrm{NH}_{4}\right)_{2}\left[\left[\mathrm{~V}_{4}^{\mathrm{IV}}\left(\mu_{4}-\mathrm{O}\right)_{2}\left(\mu_{3}-\mathrm{OH}\right)_{2}\right]\left(\mathrm{V}^{\mathrm{IV} O}\right)_{2}\left(\mu_{3}-\mathrm{SO}_{3}\right)_{4} \mathrm{O}_{4}\left(\mathrm{H}_{2} \mathrm{O}\right)_{2}\right\}, 1$}

\section{First method}

To a stirred aqueous solution $(20 \mathrm{~mL}, \mathrm{pH}=9)$ of $\left(\mathrm{NH}_{4}\right)_{2} \mathrm{SO}_{3}(2.0 \mathrm{~g}, 14.7 \mathrm{mmol})$ was added dropwise an acidic aqueous solution $(5.5 \mathrm{~mL}, \mathrm{pH}=0)$ of $\mathrm{V}^{\mathrm{IV}} \mathrm{OCl}_{2}$ [13] $(0.68 \mathrm{~g}, 4.95 \mathrm{mmol})$. Upon addition of $\mathrm{V}^{\mathrm{IV}} \mathrm{OCl}_{2}$, a sequence of color changes [from deep brown-black $(\mathrm{pH} \approx 7-8)$, through deep green $(\mathrm{pH} \approx$ $5-7)$ and green-blue $(\mathrm{pH} \approx 4)$ to blue $(\mathrm{pH} \approx 3)$ ] was induced as the $\mathrm{pH}$ of the solution was gradually falling. The solution was heated to $\approx 70{ }^{\circ} \mathrm{C}$, without magnetic stirring, for almost $6 \mathrm{~h}$, and then it was cooled to room temperature $\left(\approx 20^{\circ} \mathrm{C}\right)$ and filtered to obtain light blue crystals of 1 . Yield: $0.55 \mathrm{~g}(50 \%$, based on vanadium). Elemental analysis calc'd. (\%) for $\mathrm{H}_{14} \mathrm{NO}_{24} \mathrm{~S}_{4} \mathrm{~V}_{6}$ (860.01): H 1.64, N 3.26, $\mathrm{S}$ 14.92, V 35,54; found: H 1.75, N 3.10, S 15.10, V 25.85. [IR( $\left(\mathrm{cm}^{-1}\right): v(\mathrm{SO}): 1015(\mathrm{~m}), 995(\mathrm{~s}), 985(\mathrm{~s})$, 923(m), 880(w), 825(m); $v(\mathrm{~V}=\mathrm{O}):$ 952(vs)].

\section{Second method}

$\mathrm{NH}_{4} \mathrm{~V}^{\mathrm{V}} \mathrm{O}_{3}(0.60 \mathrm{~g}, 5.1 \mathrm{mmol})$ was dissolved in aqueous hydrochloric acid (37 \% $\mathrm{HCl}$ in water, 1:4 v/v, $20 \mathrm{~mL}, \mathrm{pH}=0)$. A solution $(15 \mathrm{~mL}, \mathrm{pH}=9)$ of $\left(\mathrm{NH}_{4}\right)_{2} \mathrm{SO}_{3}(2.0 \mathrm{~g}, 14.7 \mathrm{mmol})$ was added to it. Upon addition of $\left(\mathrm{NH}_{4}\right)_{2} \mathrm{SO}_{3}$, the yellow color of $\mathrm{NH}_{4} \mathrm{VV}_{3}$ changed to blue and the $\mathrm{pH}$ of the solution was $\approx 3$. The solution was heated to $\approx 70{ }^{\circ} \mathrm{C}$, without magnetic stirring, for $6 \mathrm{~h}$, and then it was cooled to room temperature and filtered to get light blue crystals of 1 . Yield: $0.49 \mathrm{~g}(68 \%$, based on vanadium).

\section{Synthesis of $\left(n-\mathrm{Bu}_{4} \mathrm{~N}\right)_{2}\left\{\left[\mathrm{~V}_{4}{ }^{\mathrm{IV}}\left(\mu_{4}-\mathrm{O}\right)_{2}\left(\mu_{3}-\mathrm{OH}\right)_{2}\right]\left(\mathrm{V}^{\mathrm{IV} O}\right)_{2}\left(\mu_{3}-\mathrm{SO}_{3}\right)_{4} \mathrm{O}_{4}\left(\mathrm{H}_{2} \mathrm{O}\right)_{2}\right\}, 2$}

Compound 2 was prepared in a fashion similar to that used for 1 (first method) except that $\mathrm{Na}_{2} \mathrm{SO}_{3}$ was used instead of $\left(\mathrm{NH}_{4}\right)_{2} \mathrm{SO}_{3} . n-\mathrm{Bu}_{4} \mathrm{NBr}$ (vanadium: $n-\mathrm{Bu}_{4} \mathrm{NBr}=1: 5$ ) was added to the solution just prior to heating it. Yield: $0.95 \mathrm{~g}$ ( $88 \%$, based on vanadium). Elemental analysis calc'd. (\%) for $\mathrm{C}_{32} \mathrm{H}_{78} \mathrm{~N}_{2} \mathrm{O}_{24} \mathrm{~S}_{4} \mathrm{~V}_{6}$ (1308.83): C 29.37, H 6.00, N 2.14, S 9.80, V 23.35; found: C 29.68, H 6.04, N 2.17, S 9.63, V 23.50. [IR( $\left.\mathrm{cm}^{-1}\right): v(\mathrm{SO}): 1022(\mathrm{~m}), 997(\mathrm{~s}), 987(\mathrm{~s}), 926(\mathrm{~m}), 881(\mathrm{w}), 823(\mathrm{~m}) ; v(\mathrm{~V}=\mathrm{O})$ : 951(s)].

\section{Synthesis of $\mathrm{NH}_{4}\left[\mathrm{VV}^{\mathrm{IV}} \mathrm{O}\left(\mathrm{SO}_{3}\right)_{1.5}\left(\mathrm{H}_{2} \mathrm{O}\right)\right] \cdot 2.5 \mathrm{H}_{2} \mathrm{O}, 3$}

To a stirred aqueous hydrochloric acid $(37 \% \mathrm{HCl}$ in water, $1: 4 \mathrm{v} / \mathrm{v}, 2.0 \mathrm{~mL}, \mathrm{pH}=0)$ solution of $\mathrm{NH}_{4} \mathrm{~V}^{\mathrm{V}} \mathrm{O}_{3}(0.60 \mathrm{~g}, 5.1 \mathrm{mmol})$, solid magnesium oxide $(0.59 \mathrm{~g}, 14.6 \mathrm{mmol})$ was added in one portion. Then, addition of solution of $\left(\mathrm{NH}_{4}\right)_{2} \mathrm{SO}_{3}(4.50 \mathrm{~g}, 45.9 \mathrm{mmol})$ in water $(15 \mathrm{~mL}, \mathrm{pH} \approx 9)$ to it resulted in a color change from yellow to blue-green. The final $\mathrm{pH}$ value of the solution was 4 . The solution was filtered and the filtrate was left for crystallization in an open vessel at ambient temperature $\left(\sim 20^{\circ} \mathrm{C}\right)$. After two days, blue hexagonal crystals were formed, which were filtered and dried in air to get $(1.1 \mathrm{~g}$, $30 \%$ based on vanadium) of compound 3. Elemental analysis calc'd. (\%) for $\mathrm{H}_{11} \mathrm{NO}_{9} \mathrm{~S}_{1.5} \mathrm{~V}$ (268.13): 
H 4.13, N 5.22, S 17.94, V 19.00; found: H 4.20, N 5.10, S 18.05, V 18.80. [IR(cm-1): $v(\mathrm{SO}): 1018(\mathrm{~s})$, 993(sh), 987(s), 966(sh), 903(s), 841(m); $v(\mathrm{~V}=\mathrm{O}):$ 952(s)].

\section{REFERENCES}

1. (a) E. Heath and O. W. Howarth. J. Chem. Soc., Dalton Trans. 1105 (1981); (b) L. Petterson, B. Hedman, L. Anderson, N. Ingri. Chem. Scr. 22, 254 (1983); (c) W. G. Klemperer, T. A. Marquart, O. M. Yaghi. Angew. Chem., Int. Ed. Engl. 31, 49 (1992); (d) A. Muller. J. Mol. Struct. 325, 13 (1994); (e) E. Burkholder, V. Golub, C. O’Connor, J. Zubieta. Inorg. Chem. 42, 6729 (2003); (f) E. Burkholder, S. Wright, V. Golub, C. O'Connor, J. Zubieta. Inorg. Chem. 42, 7460 (2003); (g) M. T. Pope, A Muller, A. Dress, F. Vogtle (Eds.). In From Simplicity to Complexity and Beyond, p. 137, Vieweg, Braunschweig, Germany (1996); (h) K. Wassermann, M. H. Dickmann, M. T. Pope. Angew. Chem., Int. Ed. Engl. 36, 1445 (1997).

2. (a) R. C. Haushalter and L. A. Mundi. Chem. Mater. 4, 31 (1992); (b) A. K. Cheetham, G. Ferey, T. Loiseau. Angew. Chem., Int. Ed. Engl. 38, 3268 (1999) and refs. therein; (c) C. du Peloux, A. Dolbecq, P. Mialane, J. Marrot, E. Riviere, F. Secheresse. Angew. Chem., Int. Ed. Engl. 40, 2455 (2001); (d) C. du Peloux, P. Mialane, A. Dolbecq, J. Marrot, E. Riviere, F. Secheresse. J. Mater. 11, 3392 (2001).

3. (a) M. T. Pope. Heteropoly and Isopoly Oxometalates, Springer, New York (1983); (b) M. T. Pope and A. Muller. Angew. Chem., Int. Ed. Engl. 30, 34 (1991); (c) M. T. Pope and A. Muller (Eds.). Polyoxometalates: From Platonic Solids to Anti-Retroviral Activity, Kluwer Academic, Dordrecht; (d) C. L. Hill (guest editor). Chem. Rev. 1, 111 (1998).

4. J. M. Clemente-Juan and E. Coronado. Coord. Chem. Rev. 193-195, 361 (1999), and refs. therein.

5. (a) K. Y. Matsumoto, M. Kato, Y. Sasaki. Bull. Chem. Soc. Jpn. 49, 106 (1976); (b) M. J. Manos, J. D. Woollins, A. M. Z. Slawin, T. A. Kabanos. Angew. Chem., Int. Ed. 41, 2801 (2002); (c) M. J. Manos, H. N. Miras, V. Tangoulis, J. D. Woollins, A. M. Z. Slawin, T. A. Kabanos. Angew. Chem., Int. Ed. 42, 425 (2003); (d) De-L. Long, P. Kögerler, L. Cronin. Angew. Chem., Int. Ed. 43, 1817 (2004).

6. (a) G. D. Stucky, S. R. Marder, J. E. Sohn (Eds.). Materials for Non-Linear Optics: Chemical Perspectives, American Chemistry Society, Washington DC (1991); (b) I.-C. Khoo, F. Simoni, C. Umeton (Eds.). Novel Optical Materials and Applications, John Wiley, New York (1997).

7. (a) W. T. A. Harrison, M. L. Phillips, J. Stanchfield, T. M. Nenoff. Angew. Chem., Int. Ed. Engl. 39, 3808 (2000); (b) M. G. Johnston and W. T. A. Harrison. Inorg. Chem. 40, 6518 (2001); (c) W. T. A. Harrison. Acta Crystallogr. Sect. C 55, 1980 (1999); (d) P. S. Halasyamani and D. O' Hare. Chem. Mater. 10, 646 (1998) and refs. therein; (e) W. T. A. Harrison, L. L. Dussack, A. J. Jacobson. J. Solid State Chem. 125, 234 (1996).

8. (a) R. E. Sykora, K. M. Ok, P. S. Halasyamani, T. E. Albrecht-Schmitt. J. Am. Chem. Soc. 124, 1951 (2002); (b) A. C. Bean, S. M. Pepper, T. E. Albrecht-Schmitt. Chem. Mater. 13, 1266 (2001); (c) A. C. Bean, C. F. Campana, O. Kwon, T. E. Albrecht-Schmitt. J. Am. Chem. Soc. 123, 8806 (2001); (d) R. E. Sykora, D. M. Wells, T. E. Albrecht-Schmitt. Inorg. Chem. 41, 2697 (2002).

9. C. R. Brandt and V. Eldik. Chem. Rev. 95, 119 (1995).

10. E. N. Baker and S. E. Palmer. In the Porphyrins I, D. Dolphin (Ed.), Academic Press, New York (1978).

11. K. Dimitrou, K. Folting, W. E. Streib, G. Christou. J. Chem. Soc., Chem. Commun. 1385 (1994); (b) K. Dimitrou, A. D. Brown, K. Folting, W. E. Streib, G. Christou. Inorg. Chem. 38, 1834 (1999). 
12. (a) L. Hailian, C. E. Davis, T. L. Groy, D. G. Kelley, O. M. Yaghi. J. Am. Chem. Soc. 120, 2186 (1998); (b) R. I. Walton, F. Millange, T. Loiseau, D. O’Hare, G. Fèrey. Angew. Chem., Int. Ed. 39, $4552(2000)$.

13. T. C. W. Mak, P.-J. Li, C.-M. Zheng, K.-Y. Huang. J. Chem. Soc., Chem. Commun. 904, 1597 (1986).

14. (a) B. Dawson. Acta Crystallogr. 6, 113 (1953); (b) R. Strandberg. Acta Chem. Scand. 27, 1004 (1973); (c) R. C. Haushalter and F. W. Lai. Inorg. Chem. 28, 2905 (1989); (d) M. Holscher, U. Englert, B. Zibrowius, W. F. Holderich. Angew. Chem., Int. Ed. Engl. 33, 2491 (1994); (e) A. Müller, C. Beughalt, P. Kögerler, H. Bögge, S. Bud'ko, M. Luban. Inorg. Chem. 39, 5186 (2000).

15. E. L. Solomon and A. B. Lever. Inorganic Electronic Structure and Spectroscopy, WileyInterscience, New York (1999). 